\title{
THE DEVELOPMENT OF CADASTRAL DOMAIN MODEL ORIENTED AT UNIFIED REAL ESTATE REGISTRATION OF CHINA BASED ON ONTOLOGY
}

\author{
Ming $\mathrm{Li}^{\mathrm{a}}{ }^{*}$, Xinyan Zhu ${ }^{\text {a }}$, Chenhua Shen ${ }^{\mathrm{b}}$, Di Chen ${ }^{\mathrm{a}}$, Wei Guo ${ }^{\mathrm{a}}$
}

\author{
${ }^{a}$ State Key Laboratory of Information Engineering in Surveying, Mapping and Remote Sensing, Wuhan University, 129 \\ Luoyu Road, Wuhan, hubei 430079 China - liming10307@gmail.com, geozxy@263.net \\ ${ }^{\mathrm{b}}$ Key Lab of Virtual Geographic Environment, MOE, Nanjing Normal University, 1 Wenyuan Road, Nanjing, \\ jiangsu 210046 China - shenandchen01@163.com
}

\section{Commission IV, ICWG II/IV}

KEY WORDS: GIS; Land; Land Use; Modelling; Spatial Infrastructures

\begin{abstract}
:
With the certain regulation of unified real estate registration taken by the Property Law and the step-by-step advance of simultaneous development in urban and rural in China, it is the premise and foundation to clearly specify property rights and their relations in promoting the integrated management of urban and rural land. This paper aims at developing a cadastral domain model oriented at unified real estate registration of China from the perspective of legal and spatial, which set up the foundation for unified real estate registration, and facilitates the effective interchange of cadastral information and the administration of land use. The legal cadastral model is provided based on the analysis of gap between current model and the demand of unified real estate registration, which implies the restrictions between different rights. Then the new cadastral domain model is constructed based on the legal cadastral domain model and CCDM (van Oosterom et al., 2006), which integrate real estate rights of urban land and rural land. Finally, the model is validated by a prototype system. The results show that the model is applicable for unified real estate registration in China.
\end{abstract}

\section{INTRODUCTION}

Cadastre plays an important role in managing spatial and nonspatial legal real property information to support sustainable development (Enemark et al., 2005). Since International Federation of Surveyors (FIG) shape the vision of Cadastre 2014 (Kaufmann et al., 2001), nations over the world have been put it into practice in different ways depending on their own law, culture, economy and technology (Steudler et al., 2004). However, with more cadastral information systems constructed and cadastral databases established, the barrier came out that cadastral information cannot be shared between countries and system construction has no standards. Then five years after Cadastre 2014 has been proposed, FIG developed a Core Cadastral Domain Model (CCDM) (van Oosterom et al., 2006) based on the conceptual framework of Cadastre 2014, which is one of the first presented examples of semantic geo-information domain standards. Cadastral domain model is a vital part in cadastral information system implanting and cadastral information sharing, which servers at least two goals: (1)avoid reinventing and re-implementing the same functionality over and over again, but provide an extensible basis for efficient and effective cadastral system development based on a model driven architecture (MDA), and (2)enable involved parties, both within one country and between different countries, to communicate based on the shared ontology implied by the model(van Oosterom et al., 2006).

Many studies have evaluated CCDM by applying it to different countries (Bevin, 1999; Hespanha et al., 2006; Models; Sabrah; Steudler, 2006; Van Oosterom and Lemmen, 2006). Based on these studies, they provided improved and extended versions of the existing cadastral domain model (Kalantari et al., 2006; Kaufmann, 2004; Lemmen et al., 2003). Some of them concentrated on the different parts of real property information, including real property rights, and especially the relations between the different kinds of real property information (Paasch, 2004; Paasch, 2004). Jesper M. Paasch illustrated a cadastral domain model of Swedish cadastral information, which includes the real property register, the land -, the building-, the addressand the tax-assessment register, and other registers (Paasch, 2004). Meanwhile, Jesper M. Paasch emphasized that legal and registration is an important part in cadastral information and provided a legal cadastral domain model (Paasch, 2005). Kalantari, M. later proposed a data model based on the physical land parcel be replaced by a spatially-referenced data model based on the legal property object (Kalantari et al., 2008). Zhang Weiwei developed a legal cadastral domain model of China (Zhang et al., 2008) and refined it later (Zhang et al., 2008) by an objected-oriented way, which didn't contain the contents of land administration model, land registration information and was still a basic concept model.

However, CCDM only represents the common aspects of cadastral registrations from the experience of several countries, of which most are European countries. When CCDM is applied in a specific situation, a limited number of the classes may not be needed and some classes may be added specifically (Hespanha et al., 2006). So, how to apply CCDM in China is still a challenge. And little attention has been paid to China's cadastral domain model after China's Property Law enacted in 2007, which regulates the registration of immovable objects and brought changes to land rights registration.

This paper develops a cadastral domain model oriented at unified real estate registration of China, which sets up the foundation for unified real estate registration, and facilitates the effective interchange of cadastral information and the administration of land use. On the basis of CCDM it describes the cadastral domain model both on the legal aspect and spatial

\footnotetext{
* Corresponding author. Ming Li.
} 
aspect. The model also provides technical support for the development, change, reconstruction and building of the cadastral information system.

\section{CURRENT MODEL IN CHINA}

\subsection{Land Rights System}

The core of the cadastre is land rights management. FIG states that cadastre includes land parcels, land tenure, land value, and other information that can be connected to land parcels through the unique parcel identifiers and through cadastral index maps, take buildings and other improvements for example (International Federation Of Surveyors, 1995). The statement also discussed that the land, which is the base of cadastre, may include, for example, the surface area of the earth, buildings and permanently fixed improvements, surface and subsurface resources including water, and in some instances even welldefined units of air space(International Federation Of Surveyors, 1995). That is to say cadastre management usually includes land and its accessories. However, cadastre management in China only covers a small part of land rights according to Property Law, and the accessories are excluded from rights management. . The current land rights involved in cadastral in China is shown in Figure 1.

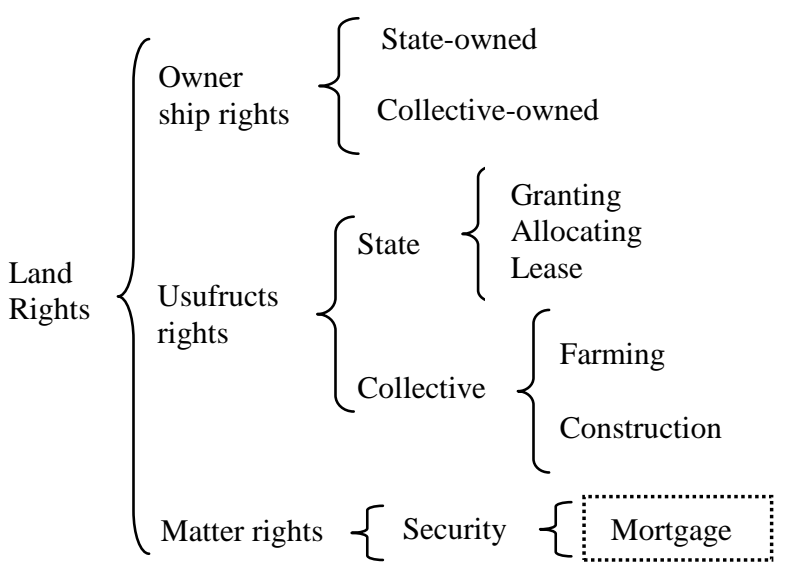

Figure 1. Land rights involved in cadastral

As depicted in Figure 1, land ownership in China is only restricted to state and collective, where individuals are not allowed to own a land. The Jus in re aliena are different depending on different land ownership. The restrictions on collective-owned land are more than that of state-owned land. The mortgage with frame in dot line means that not all lands are admitted to mortgage, take farming lands for example. From Figure 1 we can also infer that the rights of land accessories are excluded from land rights system. And the current land rights are only a small part of the complete land rights.

\subsection{Cadastral Data Model}

The current cadastral data model consists of two models according the land rights system, one of which is urban cadastral data model and the other is rural cadastral data model. The urban cadastral data model manages the land rights of stateowned land while rural cadastral data model handles the collective-owned land rights.

The urban cadastral data model, shown in Figure 2, is mainly composed of parcel, land use patch and administration area, as well as boundary systems. Buildings in the model don't contain the rights of the buildings but some attributes, like number of floors, name of owners. The administration area is covered by the land use patches seamlessly. The parcel in this model only repents the state-owned land use rights.

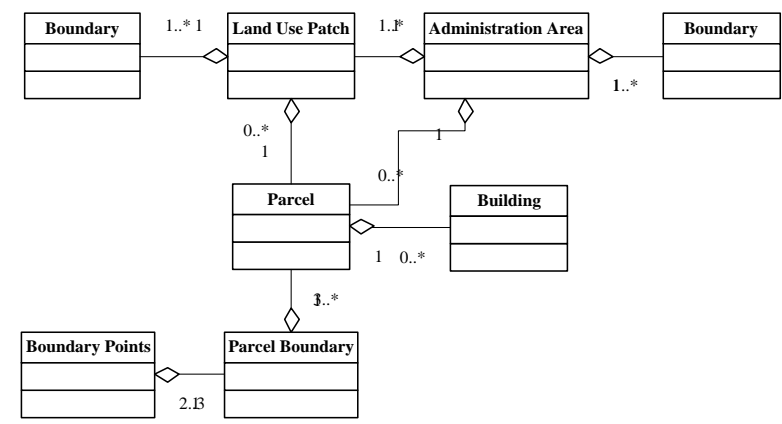

Figure 2. Urban cadastral data model

The rural cadastral data model depicted in Figure 3 is a little more complex than that of urban, which contains more components about land use objects. Parcel, administration area, land use patch and boundary systems are also embedded in the model. However, the parcel here only represents collective land ownership rights, which is different from that of urban model. So we often call parcel in rural model the ownership parcel. Linear features and point features are additional objects represent land use types. The prime cropland is a specific land that cannot be occupied during a certain land use planning period.

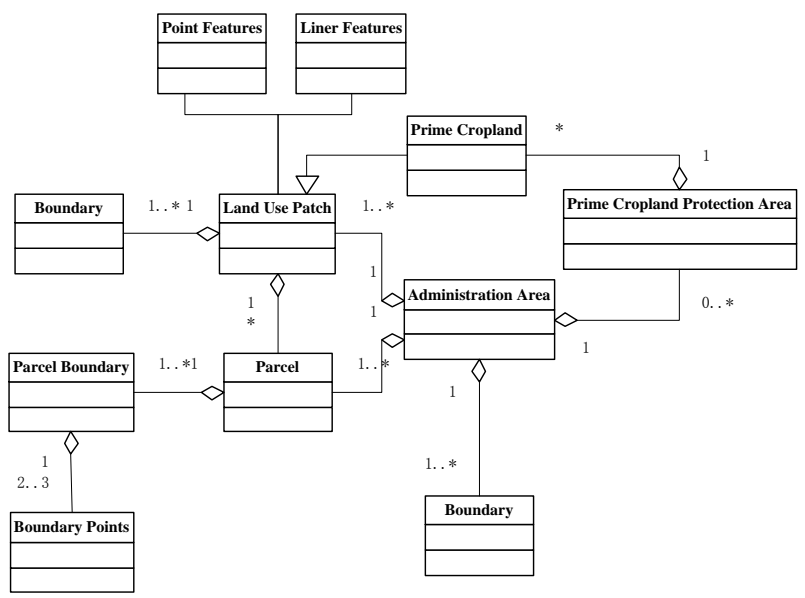

Figure 3. Rural cadastral data model

\subsection{Challenges Brought By the Property Law}

With the certain regulation of real estate registration taken by the China Property Law in 2007, the real estate registration will be integrated in a unified registry agency. Land rights system will also be regulated by Property Law. The new challenges will be as follows:

First, the current two models will be integrated as a unified model. The land use rights of collective-owned lands will be promoted with less restrictions, which can be transferred same as state-owned lands. Then the distinctions between usufruct rights of state-owned lands and collective-owned lands will be eliminated. All land rights will be integrated in one model.

Second, the cadastre in China then will be managing more land rights than now. However, from the current cadastral data 
model we can recognize that it is limited in land rights manage. For example, land use rights of collective-owned lands are excluded from the model, and mortgage is also missing. Then more parcels express and manage the rights is required to extending the current model.

Third, the relationships of cadastral objects, especially the parcel objects, need to be reanalysed. The integration and more land rights involved leads to model reconstruction. New objects will be introduced and old objects will be integrated with new ones. So relationships between different components in cadastral data model may change, which cause topological, spatial, and other relations to be reconstructed.

So, it is necessary to improve the current cadastral domain model in China, which supports the unified real estate registration.

\section{IMPROVEMENT OF CURRENT MODEL}

\subsection{Land Rights under Unified Real Estate Registration}

Property rights are categorized into ownership rights, usufructs rights and security rights according to the China Property Law. Land righs, which is an important property right, have the same classification with property rights. However, which rights will be included in real estate registration have not been confirmed. This paper presents a real estate rights system based on land rights according to the Property Law, which is consistent with that of most countries in the world (International Federation Of Surveyors, 1995), as illustrated in Figure 4. The land usufructs rights are the most active part in land systems, which can be transferred in land market. Not all the land usufructs rights are included in this paper, as the specific powers are determined by other laws which have not been legislated.

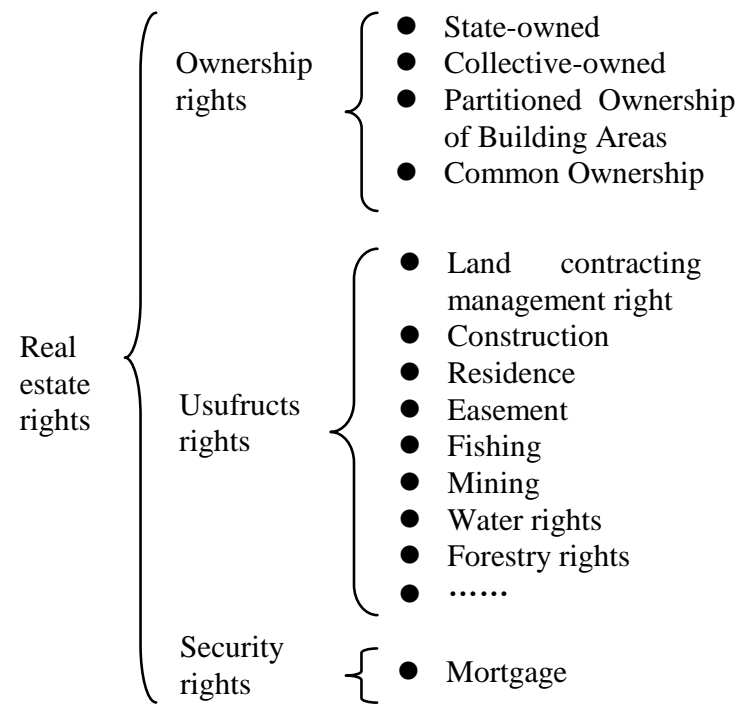

Figure 4. Real estate rights system

\subsection{Core of the Cadastral Domain Model}

Land is the most important real estate, which is the base of other real estates. Therefore, the ownership of land is the core of the real estate rights systems, which is the foundation of other land usufructs rights. The core of the cadastral domain model is depicted in Figure 5, which contains person, land ownership right and land. Person and land are connected by land ownership right, where the relations between them are many to many. It is emphasized that person here is only restricted to state and collective, but individual.

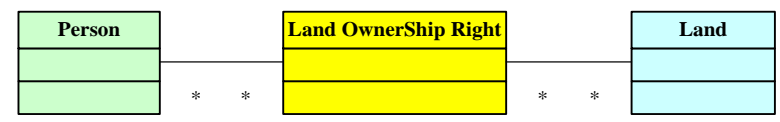

Figure 5. Core of the cadastral domain model

\subsection{Legal Cadastral Domain Model}

Based on the core of cadastral domain model, a legal cadastral domain model is proposed, which focuses on the modelling of real property rights that regulate the access to land.

Land ownership rights are divided into two categories, one of which is state-owned and the other is collective-owned. Land is state-owned except the land owned by collectives according to law. The ownership of land is forbidden to transfer in land market. The land usufructs rights based on two land owner ships are composed of construction rights and farming rights, whose subject is different. Land contracting management right, fishing right, forestry right and water right are derived from framing right. The land usufructs rights are most active part in land market in China, which can be transferred from one to another. Meanwhile, units or individuals can obtain the land usufructs by leasing or remising. The legal cadastral domain model of land ownership and usufructs rights part is shown in Figure 6.

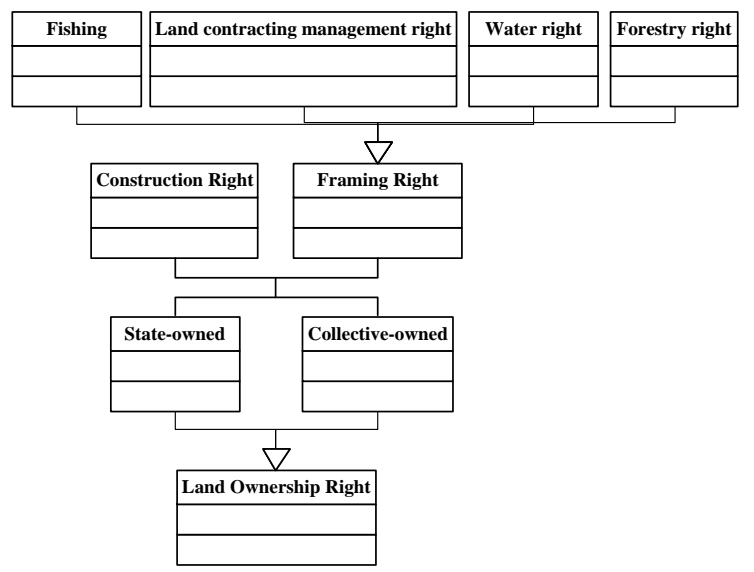

Figure 6. Land ownership and usufructs rights

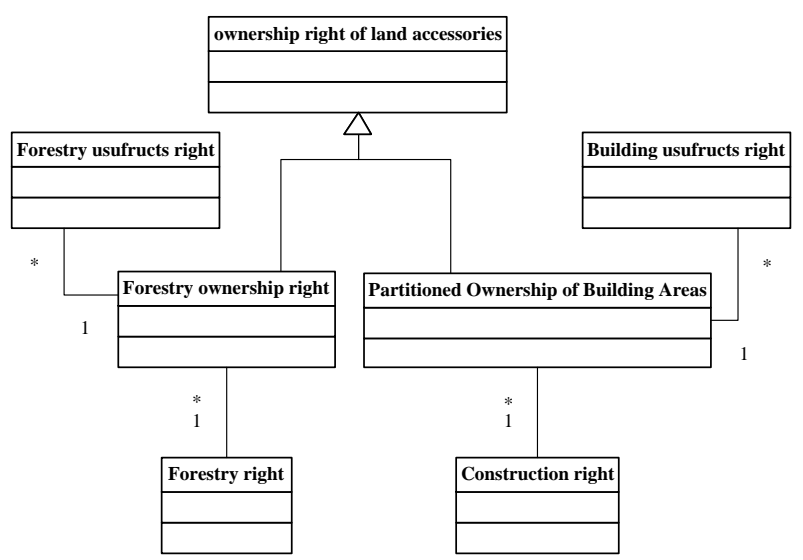

Figure 7. Land accessories ownership and usufructs rights 
The legal cadastral domain model of land accessories ownership and usufructs rights part is shown in Figure 7, which focuses on forestry and building right. The ownership of forestry and building is based on the usufructs right of land.

Mortgage is the only security right in China, based on the usufructs right of land and ownership of land accessories. The mortgaged property can be mortgaged more than one times until all the value has been mortgaged. Easement is a complex right that has no legislation in China so far. So we didn't mention it.

\subsection{New Cadastral Domain Model}

The new model is reconstructed from the current models from geospatial aspect. First, the cadastral objects from two original models are integrated. The reduplicated objects are highly abstracted, take parcel, land use patch and person class for example. Then parcels with different land rights and land accessories are extended to the model. Finally, the relationships between cadastral objects are reorganized. The model is represented by UML class diagrams, shown in Figure 8. The relationships of hierarchies and 'part-whole' between different cadastral objects are mainly depicted.

Six packages are included in the model, discriminated by different colours. Person connects with different parcels represent different relationship between person and land rights. Either the parcel, land use patch or administration area is derived from land subdivision. All cadastral spatial objects have boundary systems, like parcel boundary and parcel point with parcel.
3.4.1 Parcel Package: Parcel is the core of cadastral, which is a spatial restriction of a specific legal right. All parcels are inherited from abstract parcel class. Parcel with different types represent different land rights. It can be identified from Figure 6 and Figure 7 that parcels can be divided into four types, which are land ownership right parcel, land usufructs right parcel, mortgage parcel and land accessories usufructs right parcel. Land usufructs right parcel can be further generalized with different usufructs rights, such as forestry usufruct right, fishing usufruct right and so on. As depicted in Figure 5 and Figure 6, all land usufruct rights are based on ownership rights in China. So, the land usufruct parcel is contained by ownership parcel. And land usufruct parcel cannot be exits out of an ownership parcel. Each ownership parcel can have no usufruct parcel or contains more than one usufruct parcel.

3.4.2 Land Use Package: Land use objects are same with that of current model, which consists of land use patch, liner features, point features. The prime cropland is a special class of land use patch. However, liner features and point features appears only in rural areas, and then may exclude from a small scale cadastral database. So the relationship between point features, liner features and land use patch is many-to-zero.

3.4.3 Land Accessories Package: Buildings and forestry are two common land accessories. Forestry can only locate in forestry usufruct parcel while buildings are contained by construction usufruct parcel. Buildings are an important real estate composed of units. Each building has at least one unit.

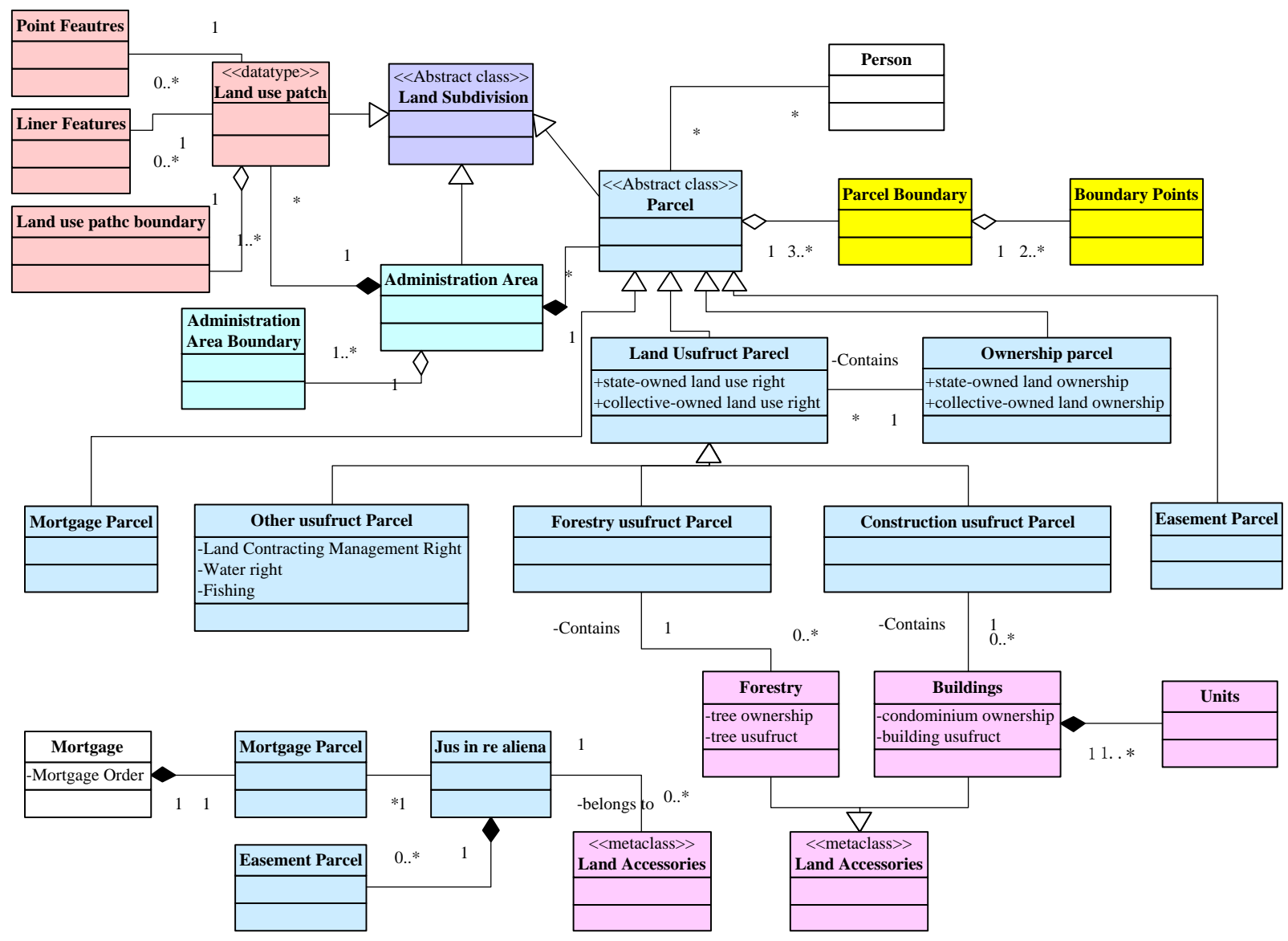

Figure 8. Cadastral domain model of China 


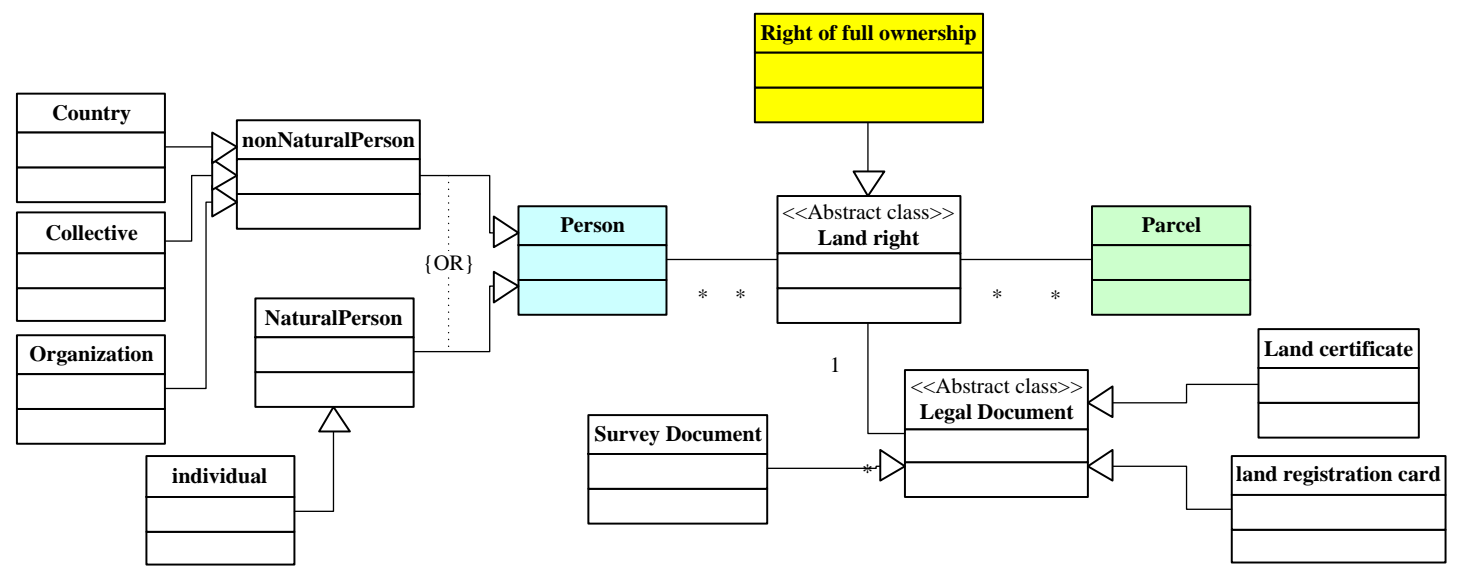

Figure 9. Person class of cadastral domain model

3.4.4 Mortgage Package: Mortgage package is in the lower left corner of Figure 8. Mortgage parcel, which has the attribute of mortgage order, is the core of Mortgage package. Each mortgage right is represented by a mortgage parcel, which must associate with a usufruct rights parcel or a land accessory. The easement parcel and land accessories are mortgaged with usufruct rights parcel.

3.4.5 Administration Area Package: Administration area objects constitute the basic units of land management. All the cadastral objects located in the boundary of administration area. Meanwhile, the administration area is covered by the land use patches seamlessly.

3.4.6 Person Package: In this class, we focus on the relation between non-spatial objects. Person is connected with parcel by land rights. The relation between person, land right and parcel are many-to-many. Person is the abstract of natural person and non-natural person. Land rights are always connected with legal documents, including survey document, land registration card and so on. The package is shown in Figure 9.

\subsection{Relationships in the Model}

The relationship mentioned here only refers to spatial topological relationship and consistence relationship between cadastral objects. Spatial topological relationship is critical for geographical information system, which have been mass involved in cadastral manage. It is also an important relationship that ensures the validity of real estate rights. Consistence relationship is attribute regulations that guaranty the correctness of estate rights. For example, the subject of building ownership rights should be same with that of land usufructs right.

Here, we only provide details about topological relationship between parcels, which is different from other models. According to the "one property one right" principle and exclusive principle, it is not permitted that setting several occupied property rights on one property at one time. The restrictions between different rights cause different relationships between cadastral objects, especially the spatial relationships between parcels. The spatial relationship between land rights includes disjoint, touch, equal and contains, shown as table 1. The topological spatial relations among exclusive rights are disjoint and touch, while others can be contains and equal.

\begin{tabular}{|c|c|c|}
\hline Parcels & Parcels & $\begin{array}{c}\text { Available } \\
\text { Spatial } \\
\text { Relation } \\
\end{array}$ \\
\hline Ownership parcel & Ownership parcel & \multirow{5}{*}{$\begin{array}{l}\text { Disjoint, } \\
\text { touch }\end{array}$} \\
\hline $\begin{array}{c}\text { Land usufructs } \\
\text { parcel }\end{array}$ & $\begin{array}{c}\text { Land usufructs } \\
\text { parcel }\end{array}$ & \\
\hline $\begin{array}{l}\text { Land accessories } \\
\text { ownership parcel }\end{array}$ & $\begin{array}{l}\text { Land accessories } \\
\text { ownership parcel }\end{array}$ & \\
\hline $\begin{array}{c}\text { Land accessories } \\
\text { usufructs right } \\
\text { parcel }\end{array}$ & $\begin{array}{c}\text { Land accessories } \\
\text { usufructs right } \\
\text { parcel }\end{array}$ & \\
\hline Mortgage parcel & Mortgage parcel & \\
\hline Ownership parcel & $\begin{array}{c}\text { Land usufructs right } \\
\text { parcel }\end{array}$ & \multirow{4}{*}{$\begin{array}{c}\text { Contains, } \\
\text { equal }\end{array}$} \\
\hline $\begin{array}{l}\text { Land usufructs } \\
\text { right parcel }\end{array}$ & $\begin{array}{l}\text { Land accessories } \\
\text { ownership parcel }\end{array}$ & \\
\hline $\begin{array}{l}\text { Land accessories } \\
\text { ownership parcel }\end{array}$ & $\begin{array}{c}\text { Land accessories } \\
\text { usufructs right } \\
\text { parcel }\end{array}$ & \\
\hline $\begin{array}{l}\text { Land usufructs } \\
\text { right parcel }\end{array}$ & Mortgage parcel & \\
\hline
\end{tabular}

Table 1. Spatial relationship between parcels

\subsection{Evaluation of the Model}

The model is evaluated by a prototype system based on urbanrural cadastral information system. Data model and functions of the system are reorganized according to the new domain model. First, new map layers are extended to represent newly added parcels, including forestry ownership parcel layer, building layer easement parcel layer. Second, cadastral data in urban and rural cadastral databases are imported and integrated. The data of two databases are in different scale and coordinate systems. Thus, the rural cadastral data is re-projected to get in accord with the urban data. However, inconsistent of data in different scale occurred even they are projected into one coordinate system, as shown in figure 9 (a) and (c). Human intervention is settled to solve the problem under the rule of high accuracy prevail. Figure 9 (b) and (d) are rectified results. Third, new business logics are employed. Since the new model is more complex than old ones, a new method for cadastral alternation is proposed to ensure the correctness of cadastral objects update (Li, M., 2010). Figure 11 depicts a land expropriation process across the rural and urban area which is supported by the new model. A rule-based data checking tool is also developed to ensure the consistency of cadastral data. Figure 12 illustrates the overlay of different real estate rights in one map in the prototype system. Inconsistence of real estate rights can 
be checked through topological relationship of parcels and other semantic consistence relationship. The results show that the

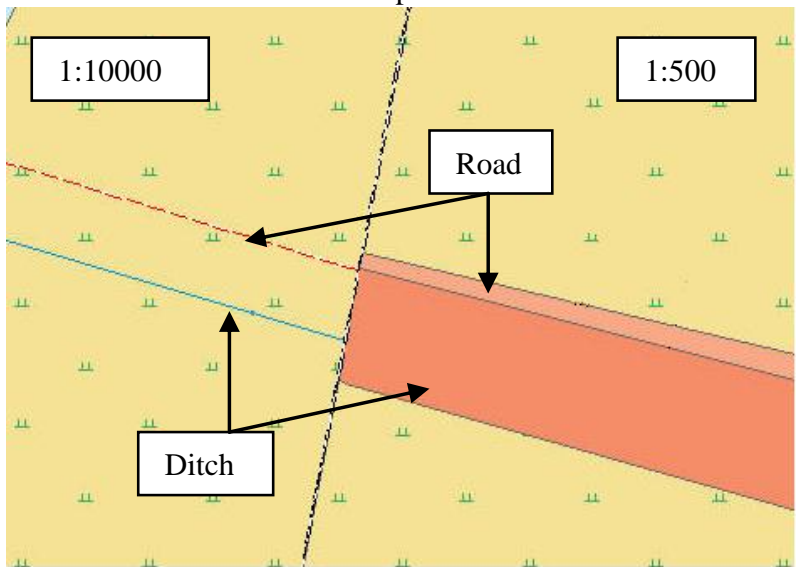

(a)

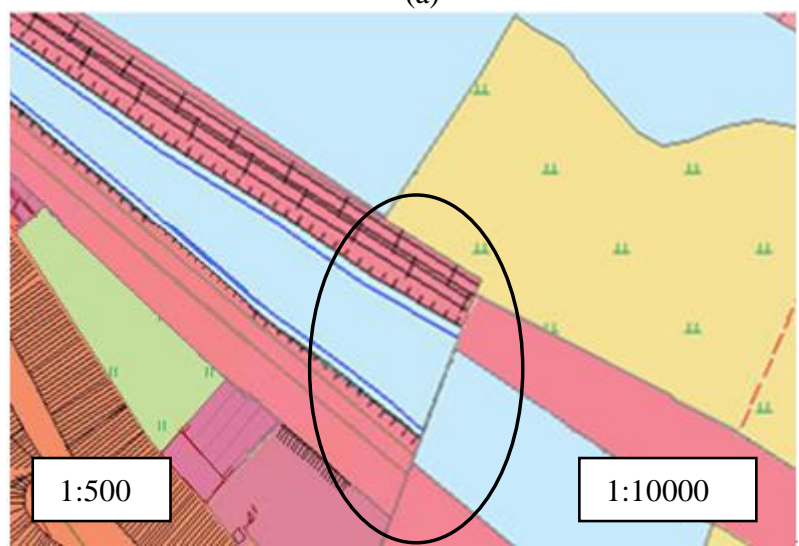

(c) proposed cadastral domain object model is available, and is also well-compatible to the existing cadastral model.

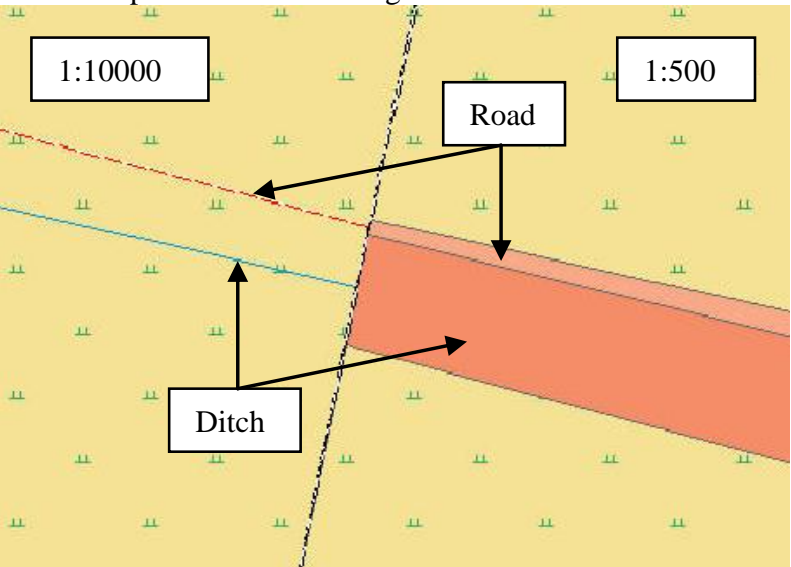

(b)

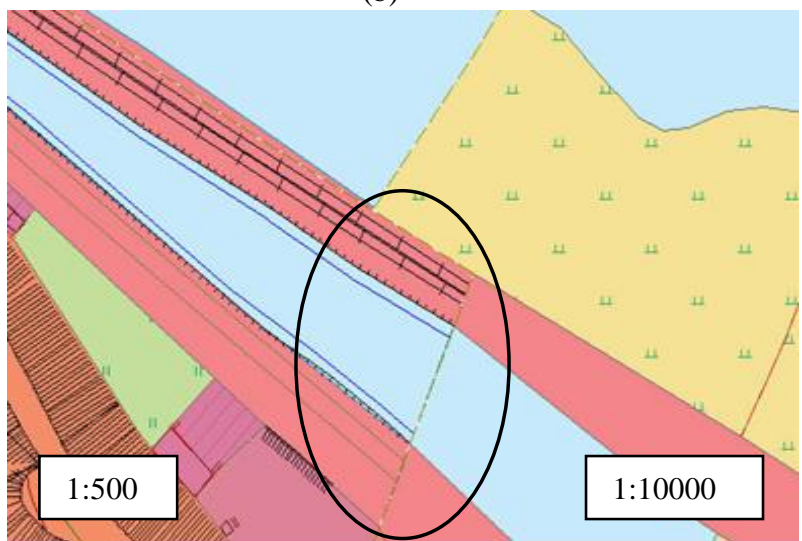

(d)

Figure 10. Data integration of urban and rural in different scale and coordinates
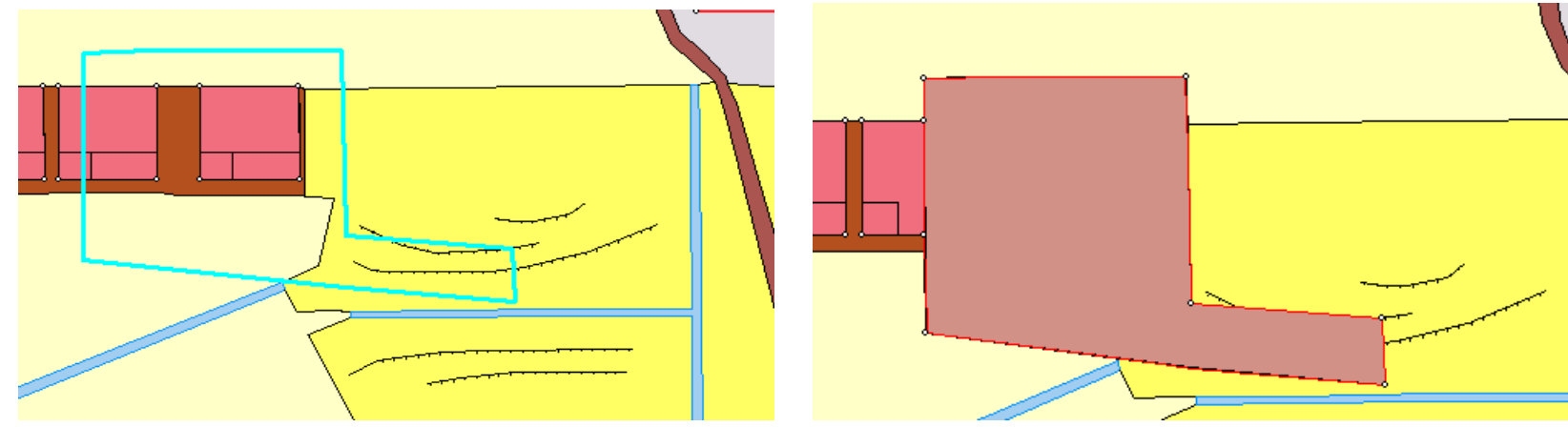

Figure 11. Cadastral change in new model
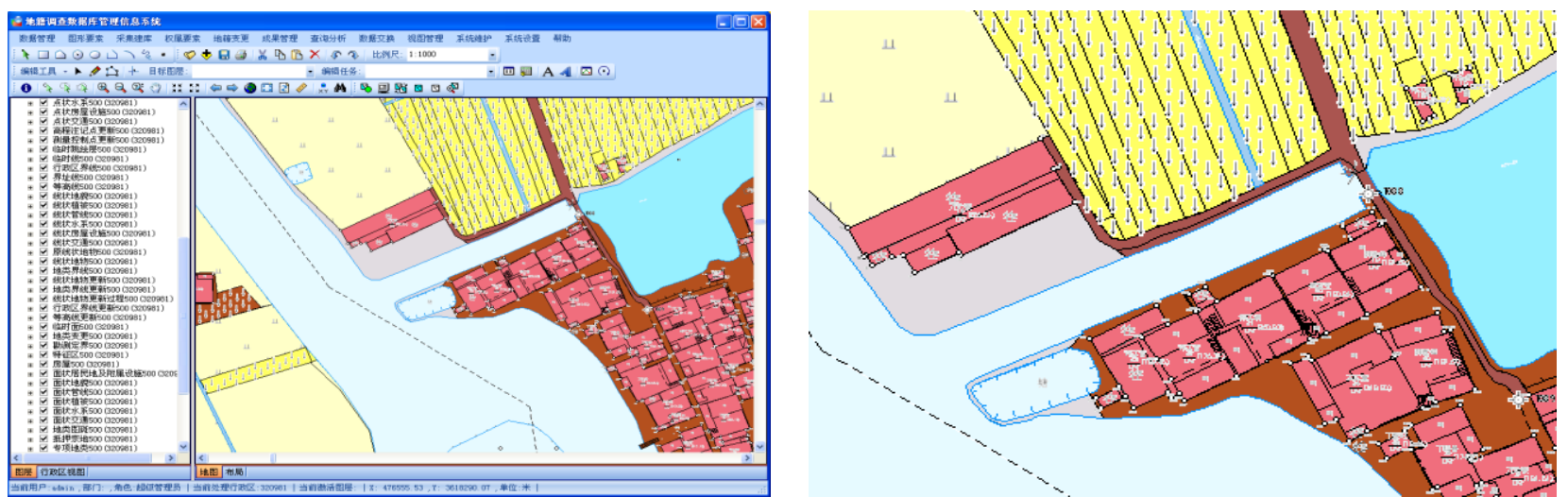

Figure 12. Prototype cadastral information system architectured by cadastral domain model 


\section{CONCUSIONS}

In summary, we have developed a cadastral domain model oriented at unified real estate registration of China, based on CCDM. The gap between current cadastral data model and unified real estate registration is first analysed. Then the legal cadastral domain model provided represents the real estate registration rights system and restrictions between different rights. Based on the legal cadastral domain model, the new cadastral domain model is reconstructed from current model, which includes parcel package, land use package, land accessories package, mortgage package, administration area package and person package. The spatial topological relationship and logical consistence relationship are also discussed. Finally, the model is evaluated by a prototype system, which integrates the real property rights discussed in this paper. When CCDM applied in Chinese cadastral, more specific cadastral objects are involved, and a natural consequence of solutions are adopted. The new model proposed in this paper integrates land rights management and cadastre in China. And it is appropriate for unified real estate registration in China.

It would be more interesting if there are dynamic aspects and 3D objects that involved in the model, which consider more about space rights and rights that cannot be expressed in $2 \mathrm{D}$ space effectively.

\section{REFERENCES}

Bevin, A.J., 1999. Cadastre 2014 Reforms in New Zealand. Proceedings of FIG Commission VII AGM, Waitangi.

Enemark, S., Williamson, I. and Wallace, J., 2005. Building modern land administration systems in developed economies. Journal of Spatial Science, Perth, Australia, 50(2): 51-68.

Hespanha, J.P., Van Oosterom, P., Zevenbergen, J. and Dias, G.P., 2006. A modular standard for the cadastral domain: Application to the Portuguese Cadastre. Computers, Environment and Urban Systems, 30(5): 562-584.

International Federation Of Surveyors, F., 1995. FIG Statement on the Cadastre.

Kalantari, M., Rajabifard, A., Wallace, J. and Williamson, I., 2006. A New Vision on Cadastral Data Model, pp. 8-13.

Kalantari, M., Rajabifard, A., Wallace, J. and Williamson, I., 2008. Spatially referenced legal property objects. Land Use Policy, 25(2): 173-181.

Kaufmann, J., 2004. Assessment of the Core Cadastral Domain Model from a Cadastre 2014 poit of view', pp. 9-10.

Kaufmann, J., Steudler, D. and Group, F.C.W., 2001. Cadastre 2014: A vision for a future cadastral system. International Federation of Surveyors.

Lemmen, C. et al., 2003. A modular standard for the Cadastral Domain. Digital Earth: 21-15.

Models, A.D., ArcGIS Cadastre 2014 Data Model Vision.

Paasch, J.M., 2004. A CADASTRAL DOMAIN MODEL. Citeseer, pp. 820-824.
Paasch, J.M., 2004. A legal cadastral domain model, pp. 9-10.

Paasch, J.M., 2005. Legal Cadastral Domain Model-An Objectoriented Approach. Nordic Journal of Surveying and Real Estate Research, 2(1): 117-136.

Sabrah, R., Online Cadastre Portal Services in the Framework of e-Government to Support Real State Industry in Egypt.

Steudler, D., 2006. Swiss cadastral core data modelexperiences of the last 15 years. Computers, Environment and Urban Systems, 30(5): 600-613.

Steudler, D., Williamson, I.P. and Rajabifard, A., 2004. A Worldwide Comparison of Cadastral Systems Cadastral Template. GIM-International Journal, 18(5): 7.

van Oosterom, P. et al., 2006. The core cadastral domain model. Computers, Environment and Urban Systems, 30(5): 627-660.

Van Oosterom, P. and Lemmen, C., 2006. The Core Cadastral Domain Model: A Tool for the Development of Distributed and Interoperable Cadastral Systems.

Zhang, W., Du, Q., Zhao, Z., Guo, Y. and Cheng, G., 2008. The further development of legal cadastral domain model of China based on ontology, pp. 71442A.

Zhang, W., Du, Q., Zhao, Z., Guo, Y. and Wang, H., 2008. A Modular Standard for the Chinese Cadastral Domain.

Li, M., 2010. The Study on Cadastral Object Model Oriented to Unified Real Estate Rights Registration, Nanjing Normal University.

\section{ACKNOWLEDGEMENTS}

The research is founded by National Science \& Technology Pillar Program (2012BAH35B03), National High Technology Research and Development Program of China (863 Program) (No. 2011AA010500), the Fundamental Research Funds for the Central Universities, and Open Research Fund of LIESMARS. The authors would like to thank the editor and reviewers for their thorough review and valuable comments. 